\title{
Refrigerated raw milk quality of a processing plant in the north of Parana after the implementation of changes imposed by NI 62 of 2011
}

\section{Qualidade do leite cru refrigerado de uma planta de processamento, no norte do Paraná, após a implementação das mudanças impostas pela IN 62 de 2011}

\author{
Fernanda Serpeloni Catanio ${ }^{1}$; Osney Massami Inay ${ }^{1}$; Alisson Santana da Silva ${ }^{2}$; \\ Juliana Ramos Pereira ${ }^{3}$; Ronaldo Tamanini ${ }^{4}$; Vanerli Beloti ${ }^{5}$; \\ Marcela de Rezende Costa ${ }^{6}$; Cínthia Hoch Batista de Souza ${ }^{7}$; \\ Lina Casale Aragon-Alegro ${ }^{7}$; Elsa Helena Walter de Santana ${ }^{7 *}$
}

\begin{abstract}
This study aimed to compare the microbiological and physicochemical quality of raw milk from individual and collective tanks, identify the psychrotrophic microbiota of refrigerated raw milk and verify compliance with current legislation. The enumeration of proteolytic and lipolytic psychrotrophs, as well as, populations of mesophilic aerobes, total coliforms, E. coli and enterobacteria was carried out. The psychrotrophic microbiota was characterized by morpho-tinctorial tests. Determination of fat content, protein, lactose, total solids, titratable acidity, cryoscopic index and somatic cells count (SCC) were also conducted. The average counts of mesophilic aerobes did not met the minimum quality requirements; however, the average results of SCC and the physicochemical parameters were in accordance with Brazilian legislation. The psychrotrophs counts were on average $90 \%$ of the total count of mesophilic aerobes, with psychrotrophic population of less than $6 \mathrm{log} \mathrm{CFU} / \mathrm{ml}$. A high percentage of proteolytic and lipolytic psychrotrophs in relation to psychrotrophs total counts was found. Considering the two weeks testing, there was a significant difference $(\mathrm{P}>0.05)$ between milk samples from collective and individual tanks only for total coliforms and for protein and lactose contents. Although the predominant psychrotrophic microbiota was Gram negative bacilli, but Gram positive bacteria were also found. Thus, the population of mesophilic aerobes in disagreement with the legislation and the high counts of psychrotrophic and Gram negative population in milk are indicative that yet, there are problems in the sanitary-hygienic production, storage and transportation of refrigerated raw milk produced in the region studied. Therefore, there is a gap between the practices recommended by legislation and the actions really found in the Brazilian milk production chain.
\end{abstract}

Key words: Microbiological quality, physicochemical composition, psychrotrophs

1 Discente do Mestrado em Ciência e Tecnologia do Leite. Universidade Norte do Paraná, UNOPAR, Londrina, PR. E-mail: fer_serpeloni@hotmail.com; ozinay@hotmail.com

2 Discente do curso de Biomedicina, UNOPAR, Londrina, PR. E-mail: alissonsantana57@gmail.com

3 Médica Veterinária, Residente em Inspeção de Leite e Derivados, UNOPAR, Londrina, PR. E-mail: julianapereira.mv@hotmail. com

4 Médico Veterinário do Laboratório de Inspeção de Produtos de Origem Animal, UNOPAR, Londrina, PR. E-mail: lipoa.uel@, gmail.com

5 Prof. do Programa de Pós-graduação em Ciência Animal, UNOPAR, Londrina, PR. E-mail: neli@sercomtel.com.br

6 Prof $^{\mathrm{a}}$. da Faculdade de Medicina Veterinária e Zootecnia, Universidade Federal de Mato Grosso de Sul. Campo Grande, MS. E-mail: marcela.rezende@ufms.br

7 Profs. do Mestrado em Ciência e Tecnologia do Leite, UNOPAR, Londrina, PR. E-mail: cinthiahoch@yahoo.com.br; lcalegro@ yahoo.com.br; elsahws@hotmail.com

Author for correspondence

Recebido para publicação 08/1 1/12 Aprovado em 14/12/12 


\title{
Resumo
}

\begin{abstract}
Este estudo teve como objetivo comparar a qualidade microbiológica e físico-química de leite cru proveniente de tanques individuais e coletivos, identificar a microbiota psicrotrófica do leite cru refrigerado e verificar o cumprimento da legislação vigente para este alimento. Realizou-se a contagem da microbiota de psicrotróficos, proteolíticos, lipolíticos, aeróbios mesófilos, coliformes totais, E. coli e enterobactérias. A microbiota psicrotrófica foi caracterizada através de testes morfotintoriais. Análises dos teores de gordura, proteína, lactose, sólidos totais, acidez titulável, índice crioscópico e contagem de células somáticas (CCS) também foram realizados. As contagens médias de aeróbios mesófilos não atenderam aos requisitos mínimos de qualidade, já os resultados médios de CCS e os parâmetros físicoquímicos estudados estavam de acordo com a legislação vigente. A contagem de psicrotróficos foi, em média, $90 \%$ da contagem total de aeróbios mesófilos, com contagens de psicrotróficos menores que 6 $\log \mathrm{UFC} / \mathrm{ml}$. Foi encontrada alta porcentagem de proteolíticos e lipolíticos em relação à contagem total de psicrotróficos. Considerando as duas semanas de análise, houve diferença significativa $(\mathrm{P}>0,05)$ entre as amostras de leite provenientes de tanques coletivos e individuais somente para coliformes totais e para os teores de proteína e lactose. A microbiota psicrotrófica predominante foi de bacilos Gram negativos, porém também foram encontrados microrganismos Gram positivos Assim a população de aeróbios mesófilos em desacordo com a legislação, a alta frequência de psicrotróficos e a presença de uma alta população de Gram negativos no leite são indicativos de que ainda há problemas higiênico sanitários na produção, armazenamento e transporte do leite cru refrigerado produzido na região estudada. Desta forma, entende-se que ainda há uma distância entre o preconizado pela legislação e a realidade encontrada.
\end{abstract}

Palavras-chave: Composição química, qualidade microbiológicas, microrganismos psicrotróficos

\section{Introduction}

The milk produced in Brazil is generally low quality, once it contains high bacteria and somatic cells counts as a consequence of poor hygiene and inadequate sanitation (LANGONI et al., 2011; MARTINS et al., 2008; MELO et al., 2010; NERO; VIÇOSA; PEREIRA, 2009), which may alter the its nutritional value (FONSECA; SANTOS, 2000). Several intrinsic and extrinsic factors such as cooling, transportation and storage of milk before processing can affect the composition and quality of the final product (FONSECA; SANTOS, 2000).

According to standards established by Normative Instruction 62 (BRASIL, 2011) milk cooling must occur on the dairy farm at $4{ }^{\circ} \mathrm{C}$ in expansion tanks or $7{ }^{\circ} \mathrm{C}$ in immersion tanks. The milk must be stored for up to 48 hours in individual or collective refrigerated tanks and subsequently transported in isothermal tank trucks to a processing plant. Given these storage conditions, refrigerated raw milk produced in the South and Southeast regions can reach a maximum of 600,000 CFU of mesophilic bacteria/mL and 600,000 somatic cells/ mL (BRASIL, 2011).

The cooling process to which the milk is submitted after milking and during transportation aims to reduce the population of mesophilic microorganisms that multiply at $25-30{ }^{\circ} \mathrm{C}$ (ARCURI et al., 2006; ROBINSON, 1987). However, rapid cooling and cold storage favor the growth of psychrotrophic bacteria which may grow at $7{ }^{\circ} \mathrm{C}$ or less although its optimum temperature is higher (FRANK; CHRISTEN; BULLERMAN, 1992).

The psychrotrophic bacteria found in milk are mostly Gram negative and the genus Pseudomonas is the most common psychrotrophic bacteria causing deterioration in fresh milk (ARCURI et al., 2008; PINTO; MARTINS; VANETTI, 2006). These bacteria are capable of producing thermoresistant extracellular proteases and lipases at refrigeration temperatures (ARCURI et al., 2008; COUSIN, 1982; CRAVEN; MACAULEY, 1992; MUIR, 1996; TEBALDI et al., 2008; VIDAL-MARTINS et al., 2005). 
The psychrotrophic bacteria existing in raw milk may come from the environment or milking equipments (FAGUNDES et al., 2006; SANTANA et al., 2001; SILVA et al., 2011; YAMAZI et al., 2010). Thus, the refrigeration process does not ensure the microbiological quality of the milk until it arrives at processing plant, being important a correct handling with good milking practices (GUERREIRO et al., 2005; SILVA et al., 2011; VALLIN et al., 2009; YAMAZI et al., 2010).

This study aimed to verify the physicochemical and microbiological quality of refrigerated raw milk from individual and collective tanks of a processing plant in the North of Parana. The psychrotrophic microbiota and compliance with current legislation was also verified.

\section{Material and Methods}

\section{Sampling}

Samples of refrigerated raw milk were collected from isothermal tank trucks (3000 L capacity) on a receiving platform of a milk processing plant located in the North of Parana in the period from October to November 2011. The raw milk was sampled at 2-week intervals, totalizing 6 samples from collective refrigerated tanks and 14 samples from individual refrigerated tanks.

An average volume of $300 \mathrm{~mL}$ was collected from each truck in sterile vials that were kept under refrigeration $\left(7^{\circ} \mathrm{C}\right)$ for a maximum of two hours and transported to the Laboratory of Master's Degree in Dairy Science and Technology at the North Parana University to perform microbiological analysis, determination of cryoscopic index and titratable acidity. An aliquot of $70 \mathrm{ml}$ was collected into vials and added preservative bronopol (2-bromo2-nitropropane-1,3-diol) for determination of physicochemical parameters and somatic cells count (SCC) in Parana Dutch Breeders Association (APCBRH, Curitiba, PR).

\section{Laboratory analyses}

\section{Microbiological characterization}

Decimal dilutions of the samples were prepared in peptone saline solution at $0.1 \%$ for enumeration of different microorganisms (BRASIL, 2003). The enumeration of mesophilic aerobes, total coliforms and $E$. coli and enterobacteria were performed by Petrifilm ${ }^{\mathrm{TM}}$ System in AC, EC and EB plates, respectively, as recommended by the manufacturer (3M Company) (HOUGHTBY et al., 1992; SILVA et al., 2007). The psychrotrophs count was performed by incubation of appropriate dilutions on Plate Count Agar (PCA) kept at $21^{\circ} \mathrm{C}$ for $25 \mathrm{~h}$ (FRANK; CHRISTEN; BULLERMAN, 1992).

The lipolytic and proteolytic activity of psychrotrophs was evaluated in tributyrin agar and milk agar, respectively after $21{ }^{\circ} \mathrm{C}$ for $72 \mathrm{~h}$ (FRANK; CHRISTEN; BULLERMAN, 1992). All counts were expressed as CFU (colony forming units) per ml sample.

\section{Characterization of psychrotrophic microbiota}

From plates containing 30 colonies for each sample, 90 colonies from milk stored in collective tanks and 210 colonies from individual tanks were selected to characterize the psychrotrophic microbiota. All colonies were characterized by Gram staining (SILVA et al., 2007).

\section{Physicochemical characterization}

The determination of cryoscopic index $\left({ }^{\circ} \mathrm{H}\right)$ (electronic cryoscope PZL-7000) and titratable acidity ( ${ }^{\circ}$ Dornic) were performed in the Laboratory of Master's Degree in Dairy Science and Technology at the North Parana University (Campus Piza) as described by AOAC methodology (ASSOCIATION OF OFFICIALANALYTICAL CHEMISTS, 1995).

The somatic cells count (SCC) (cells $/ \mathrm{mL}$ ) was performed by flow cytometry (Somacount 300-Bentley Instruments, Inc) and the determination 
of fat content ( $\%)$, protein $(\%)$, lactose $(\%)$ and total solids $(\%)$ were performed by infrared (Bentley 2000, Bentley Instruments, Inc.) according to IDF methodology (INTERNATIONAL DAIRY FEDERATION, 2000). These analyses were performed in the laboratory of Parana Dutch Breeders Association (APCBRH), which is accredited in Parana Dairy Herd Analysis Program.

\section{Statistical analysis}

The physicochemical and microbiological results were evaluated by Analysis of Variance (ANOVA) and Tukey's test $(\mathrm{P}<0.05)$ using Statistica (STATSOFT, 2008). Data were presented as mean, standard deviation (SD) and coefficient of variation $(\mathrm{CV})$, the latter being considered low $(<10 \%)$, medium (10-20\%), high (20-30\%) and very high (> 30\%) (PIMENTEL-GOMES, 1990).

\section{Results and discussion}

\section{Microbiological analyses}

The enumeration of mesophilic aerobes presented little variation $(\mathrm{CV}<10 \%)$ between the samples from collective and individual tanks. Although the largest populations of microorganisms have been found in the collective tanks, there was no significant difference $(\mathrm{P}>0.05)$ between the total counts in both tanks (Table 1). The same results were found by Pinto, Martins e Vanetti (2006) in Minas Gerais State. On the other hand, Martins et al. (2008) obtained a significantly higher $(\mathrm{P}<0.05)$ bacterial count in milk samples from expansion collective tanks than that obtained in the individual tanks in Goiás State.

Table 1. Bacterial population ( $\log \mathrm{CFU} / \mathrm{mL}$ ) of raw milk samples from refrigerated collective and individual isothermal truck tanks collected in the receiving platform of a dairy plant in October and November 2011 in Londrina, PR.

\begin{tabular}{crrrrrr}
\hline & \multicolumn{3}{c}{ Colletive tanks } & \multicolumn{3}{c}{ Individual tanks } \\
\cline { 2 - 7 } Bacteria & \multicolumn{1}{c}{ Sem. 1 } & \multicolumn{1}{c}{ Sem. 2 } & \multicolumn{1}{c}{ Geral } & \multicolumn{1}{c}{ Sem. 1 } & \multicolumn{1}{c}{ Sem. 2 } & \multicolumn{1}{c}{ Geral } \\
\hline Psychrotrophs & $5.7 \pm 0.3^{\mathrm{a}}$ & $5.7 \pm 0.4^{\mathrm{a}}$ & $5.7 \pm 0.3^{\mathrm{a}}$ & $4.8 \pm 1.5^{\mathrm{a}}$ & $5.5 \pm 0.6^{\mathrm{a}}$ & $5.2 \pm 1.1^{\mathrm{a}}$ \\
& $\left(5.9^{\mathrm{a}}\right.$ & $(6.8)$ & $(6.1)$ & $(30.0)$ & $(10.4)$ & $(20.2)$ \\
Mesophilic aerobes & $6.0 \pm 0.6^{\mathrm{a}}$ & $6.2 \pm 0.3^{\mathrm{a}}$ & $6.1 \pm 0.4^{\mathrm{a}}$ & $6.0 \pm 0.6^{\mathrm{a}}$ & $6.0 \pm 0.5^{\mathrm{a}}$ & $6.0 \pm 0.5^{\mathrm{a}}$ \\
& $(9.7)$ & $(4.1)$ & $(6.8)$ & $(9.3)$ & $(8.9)$ & $(8.7)$ \\
Proteolytic & $4.7 \pm 0.9^{\mathrm{a}}$ & $6.0 \pm 0.3^{\mathrm{a}}$ & $5.5 \pm 0.9^{\mathrm{a}}$ & $5.2 \pm 1.1^{\mathrm{a}}$ & $5.2 \pm 0.6^{\mathrm{b}}$ & $5.2 \pm 0.8^{\mathrm{a}}$ \\
& $(19.5)$ & $(5.6)$ & $(15.8)$ & $(21.3)$ & $(11.0)$ & $(15.6)$ \\
Lipolytic & $5.4 \pm 0.4^{\mathrm{a}}$ & $6.0 \pm 0.5^{\mathrm{a}}$ & $5.8 \pm 0.5^{\mathrm{a}}$ & $5.4 \pm 0.9^{\mathrm{a}}$ & $5.4 \pm 0.7^{\mathrm{a}}$ & $5.4 \pm 0.8^{\mathrm{a}}$ \\
& $(6.6)$ & $(7.6)$ & $(8.7)$ & $(17.4)$ & $(13.2)$ & $(14.8)$ \\
Enterobacteria & $4.9 \pm 1.0^{\mathrm{a}}$ & $5.5 \pm 0.7^{\mathrm{a}}$ & $5.2 \pm 0.8^{\mathrm{a}}$ & $4.0 \pm 0.8^{\mathrm{a}}$ & $5.1 \pm 0.6^{\mathrm{a}}$ & $4.5 \pm 0.9^{\mathrm{a}}$ \\
& $(20.5)$ & $(12.3)$ & $(16.1)$ & $(19.5)$ & $(12.7)$ & $(19.5)$ \\
Coliforms & $4.4 \pm 0.9^{\mathrm{a}}$ & $4.1 \pm 0.2^{\mathrm{a}}$ & $4.2 \pm 0.6^{\mathrm{a}}$ & $3.2 \pm 0.9^{\mathrm{a}}$ & $3.4 \pm 0.6^{\mathrm{a}}$ & $3.3 \pm 0.8^{\mathrm{b}}$ \\
& $(21.3)$ & $(4.9)$ & $(15.2)$ & $(29.7)$ & $(18.5)$ & $(23.7)$ \\
E. coli & $2.9 \pm 0.6^{\mathrm{a}}$ & $3.5 \pm 0.6^{\mathrm{a}}$ & $3.2 \pm 0.6^{\mathrm{a}}$ & $3.0 \pm 1.0^{\mathrm{a}}$ & $3.6 \pm 0.7^{\mathrm{a}}$ & $3.3 \pm 0.9^{\mathrm{a}}$ \\
& $(20.4)$ & $(17.2)$ & $(19.2)$ & $(35.5)$ & $(19.8)$ & $(28.2)$ \\
\hline
\end{tabular}

a,b: Values (mean \pm standard deviation) with the same letters in the same row for each period studied (Sem 1, Sem 2 and General) are not statistically different $(\mathrm{P}>0.05)$.

* Values in parentheses $=$ coefficient of variation.

Source: Elaboration of the authors. 
Similar to this study, populations above the limit established by law were observed by other authors. Borges et al. (2009) in Rio Grande do Sul State and Mattos et al. (2010) in Pernambuco State found average counts of $6.03 \log \mathrm{CFU} / \mathrm{mL}$ and 6.22 $\log \mathrm{CFU} / \mathrm{mL}$ for mesophilic aerobes in samples of refrigerated raw milk.

The mean counts of psychrotrophs in milk from collective tanks were higher (5.7 log CFU/ $\mathrm{mL}$ ) than those of individual tanks (5.2 log CFU/ $\mathrm{mL})$ (Table 1) with no significant difference (P> 0.05). According to some authors psychrotrophic populations in refrigerated raw milk are higher in collective rather than individual tanks (ARCURI et al., 2008; MARTINS et al., 2008; PINTO; MARTINS; VANETTI, 2006).

Comparing the results for psychrotrophs within two days of collection, there was a little variation in samples from collective tanks and medium-high variation in samples from individual tanks. The greatest variation in the results shows that good practices implemented to improve milk quality have not been consistently effective.

All psychrotrophs counts were lower than mesophilic aerobes counts, presenting a mean percentage of psychrotrophs in relation to mesophilic aerobes of $93.5 \%$ and $86.7 \%$ for collective and individual tanks, respectively. The high percentage of psychrotrophs is an indication of poor hygiene during milking and failures during storage and transportation of refrigerated milk. In adequate sanitary conditions, psychrotrophic bacteria represent less than $10 \%$ of the total microbiota of raw milk; however, in unsatisfactory handling the psychrotrophic microorganisms can exceed $75 \%$ (SUHREN, 1989).

A minimum number of psychrotrophs is required for extracellular enzymes (proteases and lipases) produced by these bacteria promote changes in milk and dairy products, with values ranging from $10^{6}$ to $10^{7} \mathrm{CFU} / \mathrm{mL}$ (FURTADO, 1999; MAHIEU, 1991, MUIR, 1990). In this study, the mean counts of psychrotrophic bacteria in individual and collective tanks were below $10^{6} \mathrm{CFU} / \mathrm{mL}$ ( 6 UFC $\log / \mathrm{mL}$ ) for the majority of samples. However, failures in sanitary handling and inadequate temperature and time of storage may easily increase psychrotrophs counts, which cause sensory changes in the product due to the activity of proteases and/or lipases.

The average population of proteolytic and lipolytic psychrotrophs were higher in milk from collective tanks, but the difference was significant $(\mathrm{P}<0.05)$ only for proteolytic bacteria in the second week collection (Table 1). Proteolytic and lipolytic microorganisms accounted for over $95 \%$ of the total psychrotrophic bacteria, which varied from low to medium counts within the two weeks study (Table 1). Pinto, Martins e Vallin (2006) found a significant difference in proteolytic bacteria counts in milk samples from individual and collective tanks. However, the values obtained by these authors were $1.5 \log \mathrm{CFU} / \mathrm{mL}$ lower than those observed in this study.

Enterobacteria are represented by Gram negative bacteria, which are hygienic indicators in the manufacturing processes. Although there is no limit for these microorganisms in raw milk, some genres are environmental contaminants, pathogens for humans and may confer changes in food flavor. In this study the population of enterobacteria was on average $5.2 \log \mathrm{CFU} / \mathrm{ml}$ in milk from the collective tanks and $4.5 \log \mathrm{CFU} / \mathrm{ml}$ in milk from the individual tanks, the latter showing a significant difference $(\mathrm{P}<0.05)$ in the populations within two weeks collection (Table 1). As shown in Table 1, an average variation in the population of enterobacteria was observed in milk samples from both tanks.

Considering the two-week analyses of this study, a significant difference $(\mathrm{P}<0.05)$ in the population of coliforms in the individual and collective tanks was observed, but there was no difference in $E$. coli counts (Table 1). The counts of collective and individual tanks presented medium and high $\mathrm{CV}$ for these microorganisms, respectively. Values 
above those found in this study were observed by Mattos et al. (2010), who studied refrigerated raw milk and found 98\% samples presenting total coliforms population above $6 \log \mathrm{CFU} / \mathrm{ml}$ and $E$. coli population varying from 3.55 and $5.25 \mathrm{log}$ $\mathrm{CFU} / \mathrm{mL}$.

The results obtained in this study show that the hygienic conditions of milking were unsatisfactory, although there is no established limit for total coliforms and E. coli populations in raw milk. Literature recommends that the populations of total coliforms may not exceed $100 \mathrm{CFU} / \mathrm{mL}$ (CHAMBERS, 2002). The presence of E. coli is an indicator of fecal contamination and presence of bacterial pathogens; in addition, some strains are pathogenic for humans and animals (FRANCO; LANDGRAF, 2004).

\section{Physicochemical analyses}

According to IN 62 2011, the refrigerated raw milk must contain minimum of $3 \%$ fat, $8.4 \%$ nonfat dry matter, $2.9 \%$ protein and $11.4 \%$ total solids. It must present alcohol stability when tested with Alizarol of $72 \%$ strength, titratable acidity between 0.14 to $0.18 \mathrm{~g}$ of lactic acid/100 $\mathrm{mL}\left(14\right.$ to $\left.18{ }^{\circ} \mathrm{D}\right)$ and cryoscopic index from -0.530 to $-0.550{ }^{\circ} \mathrm{H}$. The lactose content is not established by legislation, but the literature describes values between 3.8 and $5.3 \%$, with mean value of $4.6 \%$ (WALSTRA; WOUTERS; GEURTS, 2006).

Based on the reference values, all samples attended the criteria for fat content, protein, lactose, total solids, acidity and cryoscopic index as shown in Table 2. Moreover, all the samples were stable at Alizarol 72\%.

There was a poor variation of the parameters protein, lactose, total solids and cryoscopic index within the two collections and a medium $\mathrm{CV}$ for fat content and titratable acidity. The somatic cells count (SCC) of the samples from both tanks met the minimum requirements for quality, which is $600 \mathrm{x}$ $10^{3}$ cells/mL (BRASIL, 2011) (Table 2).

There was a significant difference $(\mathrm{P}<0.05)$ between milk samples from individual and collective tanks for protein content, acidity and cryoscopic index in the first week analysis. Significant difference $(\mathrm{P}<0.05)$ was also observed on protein and lactose contents in the second week study in both tanks, with higher lactose content in the collective tanks (Table 2).

Milk composition may be influenced by several factors such as animal breeding, stage of lactation, diet type, season, age and number of births (NORO et al., 2006; WALSTRA; WOUTERS; GEURTS, 2006). Within each race, the milk composition may vary as a result of genetic selection and the quality and management of diet (WALSTRA; WOUTERS; GEURTS, 2006).

Considering the two-week collection, milk samples from collective tanks showed significant difference $(\mathrm{P}<0.05)$ in the parameter acidity, with higher values in the first week collection $(\mathrm{P}<0.05)$ in milk from individual tanks, which may be associated with the higher levels of protein found in these samples (WALSTRA; WOUTERS; GEURTS, 2006). The samples from individual tanks presented significant difference $(\mathrm{P}<0.05)$ in fat content and total solids (Table 2).

As exhibited in Figure 1, the Gram negative microbiota predominated in the samples with $64.41 \%$ in the collective tanks and $66.71 \%$ in the individual tanks. Among the psychrotrophs there was predominance of Gram negative bacilli in the collective (47.8 \%) and individual tanks (51.9\%). According to Hantsis-Zacharov e Halpern (2007), monitoring the predominant psychrotrophic species responsible for the production of heat resistant enzymes offers an efficient tool in improving the milk quality. 
Table 2. Physicochemical parameters of raw milk samples from refrigerated collective and individual isothermal truck tanks collected in the receiving platform of a dairy plant in October and November 2011 in Londrina, PR.

\begin{tabular}{crrrrrr}
\hline & \multicolumn{3}{c}{ Collective Tanks } & \multicolumn{3}{c}{ Individual Tanks } \\
\cline { 2 - 6 } Parameters & \multicolumn{1}{c}{ Sem. 1 } & \multicolumn{1}{c}{ Sem. 2 } & \multicolumn{1}{c}{ Geral } & \multicolumn{1}{c}{ Sem. 1 } & \multicolumn{1}{c}{ Sem. 2 } & General \\
\hline Fat & $3.77 \pm 0.81^{\mathrm{a}}$ & $3.76 \pm 0.39^{\mathrm{a}}$ & $3.77 \pm 0.61^{\mathrm{a}}$ & $3.40 \pm 0.30^{\mathrm{a}}$ & $4.01 \pm 0.75^{\mathrm{a}}$ & $3.72 \pm 0.66^{\mathrm{a}}$ \\
$(\%)$ & $(21.5)^{*}$ & $(10.5)$ & $(16.1)$ & $(9.0)$ & $(18.8)$ & $(17.7)$ \\
Protein & $3.06 \pm 0.10^{\mathrm{b}}$ & $3.10 \pm 0.03^{\mathrm{b}}$ & $3.08 \pm 0.08^{\mathrm{b}}$ & $3.18 \pm 0.12^{\mathrm{a}}$ & $3.16 \pm 0.07^{\mathrm{a}}$ & $3.17 \pm 0.10^{\mathrm{a}}$ \\
$(\%)$ & $(3.4)$ & $(1.0)$ & $(2.5)$ & $(3.9)$ & $(2.3)$ & $(3.2)$ \\
Lactose & $4.54 \pm 0.06^{\mathrm{a}}$ & $4.57 \pm 0.07^{\mathrm{a}}$ & $4.55 \pm 0.07^{\mathrm{a}}$ & $4.49 \pm 0.12^{\mathrm{a}}$ & $4.49 \pm 0.07^{\mathrm{b}}$ & $4.49 \pm 0.10^{\mathrm{b}}$ \\
$(\%)$ & $(1.3)$ & $(1.6)$ & $(1.5)$ & $(2.7)$ & $(1.7)$ & $(2.2)$ \\
Total Solids & $12.29 \pm 0.71^{\mathrm{a}}$ & $12.35 \pm 0.28^{\mathrm{a}}$ & $12.32 \pm 0.52^{\mathrm{a}}$ & $12.04 \pm 0.29^{\mathrm{a}}$ & $12.58 \pm 0.71^{\mathrm{a}}$ & $12.32 \pm 0.61^{\mathrm{a}}$ \\
$(\%)$ & $(5.8)$ & $(2.2)$ & $(4.2)$ & $(2.4)$ & $(5.7)$ & $(5.0)$ \\
Somatic cells & $504 \pm 230^{\mathrm{a}}$ & $454 \pm 349^{\mathrm{a}}$ & $479 \pm 288^{\mathrm{a}}$ & $494 \pm 249^{\mathrm{a}}$ & $645 \pm 370^{\mathrm{a}}$ & $570 \pm 321^{\mathrm{a}}$ \\
$\left(\mathrm{x} 10^{3} / \mathrm{mL}\right)$ & $(45.6)$ & $(77.1)$ & $(60.1)$ & $(50.3)$ & $(57.3)$ & $(56.3)$ \\
Tit. acidity & $14.67 \pm 1.00^{\mathrm{b}}$ & $18.11 \pm 2.93^{\mathrm{a}}$ & $16.39 \pm 2.77^{\mathrm{a}}$ & $15.76 \pm 0.70^{\mathrm{a}}$ & $16.85 \pm 2.66^{\mathrm{a}}$ & $16.29 \pm 1.98^{\mathrm{a}}$ \\
$\left({ }^{\circ} \mathrm{D}\right)$ & $(6.8)$ & $(16.2)$ & $(16.9)$ & $(4.4)$ & $(15.8)$ & $(12.1)$ \\
Cryoscopic index & $-533 \pm 6^{\mathrm{a}}$ & $-540 \pm 18^{\mathrm{a}}$ & $-537 \pm 14^{\mathrm{a}}$ & $-540 \pm 5^{\mathrm{b}}$ & $-541 \pm 2^{\mathrm{a}}$ & $-540 \pm 4^{\mathrm{a}}$ \\
$\left({ }^{\circ} \mathrm{H}\right)$ & $(1.2)$ & $(3.3)$ & $(2.5)$ & $(0.9)$ & $(0.5)$ & $(0.7)$ \\
\hline
\end{tabular}

a,b: Values(mean \pm standard deviation) with the same letters in the same row for each period studied (Sem 1, Sem 2 and General) are not statistically different $(\mathrm{P}>0.05)$.

Values in parentheses $=$ coefficient of variation.

Source: Elaboration of the authors.

Pseudomonas is the Gram negative species most commonly isolated from refrigerated raw milk (COUSIN, 1982; FAGUNDES et al., 2006; PINTO; MARTINS; VANETTI, 2006; SORHAUNG; STEPANIAK, 1997) due to its great ability to grow in the refrigerated environment as compared to other Gram negative species (KUMARESAN et al., 2007; SMITHWELL; KAILASAPATHY, 1995), thus being considered the most common producer of lipases in milk.

Figure 1. Psychrotrophic microbiota of raw milk samples from refrigerated collective and individual isothermal truck tanks collected in the receiving platform of a dairy plant in October and November 2011 in Londrina, PR.

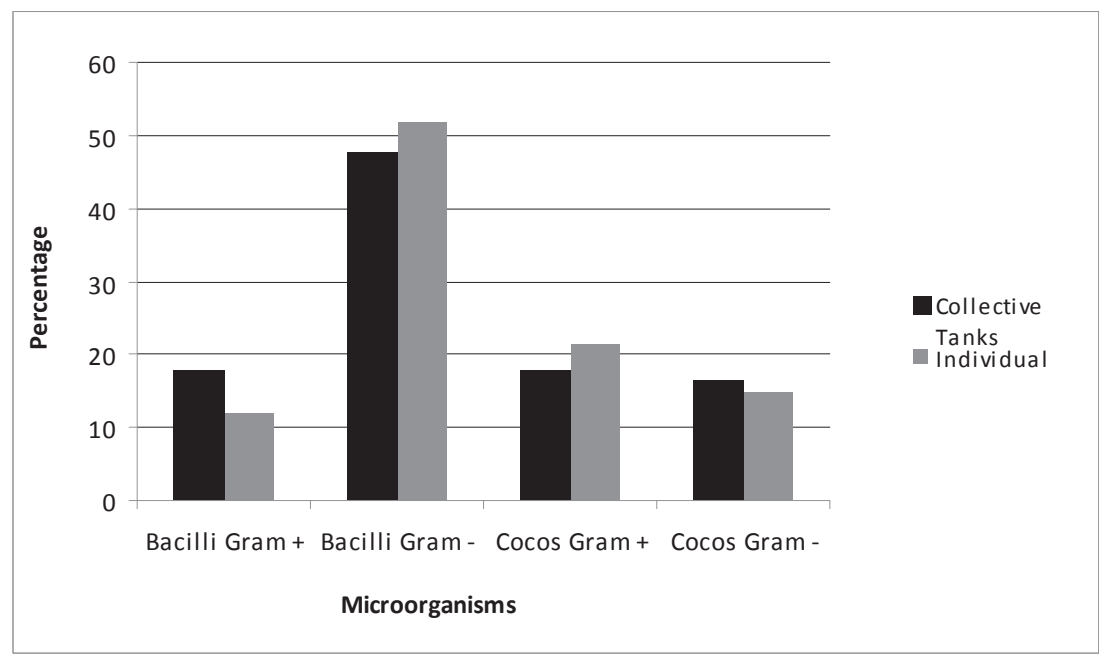

Source: Elaboration of the authors. 
Improper cleaning of the teats and bins and waste water from expansion tanks represent important sources of Gram negative bacteria incorporation to milk (SANTANA et al., 2004). Significant contamination by Pseudomonas occurs due to improper sanitizing of milking equipment and failures during storage and transportation of refrigerated milk (FAGUNDES et al., 2006; KUMARESAN et al., 2007).

Regarding the Gram positive psychrotrophs found in this study, there was a predominance of cocci $(21.4 \%)$ in milk from the individual tanks. The collective tanks presented equal frequency of cocci and bacilli (17.8\%) as can be seen in Figure 1. According to Muir (1990), the proteolytic activity of Gram positive microorganisms is low; however, some authors attribute changes in taste and quality of dairy products to the genus Bacillus (MUIR, 1996; SORHAUNG; STEPANIAK, 1997; WASHAM; OLSON; VEDAMUTHU, 1977). Andrade, Ajao and Zottola (1998) reported that Enterococcus faecium is the most abundant species detected in pasteurized refrigerated milk. Santana et al. (2004) considered Gram positive bacteria the most prevalent proteolytic psychrotrophs in milk production sector.

\section{Conclusion}

The average results of SCC and the physicochemical parameters of refrigerated raw milk delivered in reception platform is in accordance with the Brazilian legislation. However, the mean counts of mesophilic aerobes presented were in disagreement to the minimum requirements for quality.

The psychrotrophs count was on average $90 \%$ of the total count of mesophilic aerobes, with high percentage of proteolytic and lipolytic bacteria, indicating deficient hygiene during milking and failures during storage and transportation of refrigerated milk.
In general, there were significant differences between the samples from collective and individual tanks for total coliforms, protein and lactose contents.

The predominant psychrotrophic microbiota in both collective and individual tanks was Gram negative bacilli.

The microbiological results and the predominant psychrotrophs showed that even after changes implemented to improve the milk quality, there are gaps in hygienic production of milk as well as during storage and transportation, which reduces the quality of the milk and dairy products.

\section{References}

ANDRADE, N. J.; AJAO, D. B.; ZOTTOLA, E. A. Growth and adherence on stainless steel by Enterococcus faecium cells. Journal of Food Protection, Des Moines, v. 61, n. 11, p. 1454-1458, 1998.

ARCURI, E. F.; BRITO, M. A. V. P.; BRITO, J. R. F.; PINTO, S. M.; ÂNGELO, F. F.; SOUZA, G. N. Qualidade microbiológica do leite refrigerado nas fazendas. Arquivo Brasileiro de Medicina Veterinária e Zootecnia, Belo Horizonte, v. 58, n. 3, p. 440-446, 2006.

ARCURI, E. F.; SILVA, P. D. L.; BRITO, M. A. V. P.; BRITO, J. R. F.; LANGE, C. C.; MAGALHÃES, M. M. A. Contagem, isolamento e caracterização de bactérias psicrotróficas contaminantes de leite cru refrigerado. Ciência Rural, Santa Maria, v. 38, n. 8, p. 2250-2255, 2008.

ASSOCIATION OF OFFICIAL ANALYTICAL CHEMISTS - AOAC. Official methods of analysis. $16^{\text {th }}$ ed. Washington: AOAC, 1995.

BORGES, K. A.; REICHERT, S.; ZANELA, M. B.; FISCHER, V. Avaliação da qualidade do leite de propriedades da região do Vale do Taquari no estado do Rio Grande do Sul. Acta Scientiae Veterinariae, Porto Alegre, v. 37, n. 1, p. 39-44, 2009.

BRASIL. Ministério da Agricultura, Pecuária e Abastecimento. Instrução Normativa 62, de 29 de Dezembro de 2011. Aprova o Regulamento Técnico de Produção, Identidade e Qualidade do Leite tipo A, o Regulamento Técnico de Identidade e Qualidade de Leite Cru Refrigerado, o Regulamento Técnico de Identidade e Qualidade de Leite Pasteurizado e o Regulamento Técnico 
da Coleta de Leite Cru Refrigerado e seu Transporte a Granel. Diário Oficial [da] República Federativa do Brasil, Seção 1, 30 de Dezembro de 2011.

Secretaria de Defesa Agropecuária. Instrução Normativa 62, de 26 de Agosto de 2003. Oficializa os Métodos Analíticos Oficiais para Análises Microbiológicas para Controle de Produtos de Origem Animal e Água. Diário Oficial [da] República Federativa do Brasil, Brasília, 26 de agosto de 2003.

CHAMBERS, J. V. The Microbiology of raw milk. In: ROBINSON, R. K. (Ed.). Dairy microbiology handbook. New York: Wiley-Interscience, 2002. p. 39-90.

COUSIN, M. A. Presence and activity of psicrotrophic microorganisms in milk and dairy products: a review. Journal of Food Protection, Des Moines, v. 45, n. 2, p. 172-207, 1982.

CRAVEN, H. M.; MACAULEY, B. J. Microorganisms in pasteurized milk after refrigerated storage 2. Seasonal variation. Australian Journal of Dairy Technology, Melbourne, v. 47, n. 1, p. 46-49, 1992.

FAGUNDES, C. M.; FISCHER, V.; SILVA, W. P.; CARBONERA, N.; ARAÚJO, M. R. Presença de Pseudomonas spp. em função de diferentes etapas da ordenha com distintos manejos higiênicos e no leite refrigerado. Ciência Rural, Santa Maria, v. 36, n. 2, p. 568-572, 2006.

FONSECA, L. F. L.; SANTOS, M. V. Qualidade do leite e controle de mastite. São Paulo: Lemos Editorial, 2000.

FRANCO, B. D. G.; LANDGRAF, M. Microbiologia dos alimentos. Rio de Janeiro: Atheneu, 2004. 196 p.

FRANK, J. F.; CHRISTEN, G. L.; BULLERMAN, L. B. Tests for Groups of microrganisms. 16. ed. In: MARSHALL, R. T. (Ed.). Standard Methods for the examination of dairy products. New York: APHA, 1992. p. 837-856.

FURTADO, M. M. Principais problemas dos queijos: causas e prevenção. São Paulo: Fonte Comunicações e Editora, 1999.

GUERREIRO, P. K.; MACHADO, M. R. F.; BRAGA, G. C.; GASPARINO, E.; FRANZENER, A. S. M. Qualidade microbiológica de leite em função de técnicas profiláticas no manejo de produção. Ciência e Agrotecnologia, Lavras, v. 29, n. 1, p. 216-222, 2005.

HANTSIS-ZACHAROV, E.; HALPERN, M. Culturable psychrotrophic bacterial communities in raw milk and their proteolytic and lipolytic traits. Applied and Environmental Microbiology, Washington, v. 73, n. 22, p. 7162-7168, 2007.
HOUGHTBY, G. A.; MARTURIN, L. J.; KOENIG, E. K.; MESSER, J. W. Microbiological count methods. In: MARSHALL, R. T. Standard methods for the examination of dairy products. $16^{\text {th }}$ ed. Washington: American Public Health Association, 1992. p. 213-246.

INTERNATIONAL DAIRY FEDERATION. International Standard 141C. Whole milk-determination of milkfat, protein and lactose content - guidance on the operation of mid-infrared instruments. Brussels, Belgium: International Dairy Federation.

KUMARESAN, G.; ANNALVILLI, R.; SIVAKUMAR, K. Psychrotrophic spoilage of raw milk at different temperatures of storage. Journal of Applied Sciences Research, Jordan, v. 3, n. 11, p. 1383-1387, 2007.

LANGONI, H.; PENACHIO, D. S.; CITADELLA, J. C. C.; LAURINO, F.; FACCIOLI-MARTINS, P. Y.; LUCHEIS, S. B.; MENOZZI, B. D.; SILVA, A. V. Aspectos microbiológicos e de qualidade do leite bovino. Pesquisa Veterinária Brasileira, Rio de Janeiro, v. 31, n. 12, p. 1059-1065, 2011.

MAHIEU, H. Modificaciones de la leche después de su recogida. In: LUQUET, F. M. Leche y productos lácteos. la leche de la mama a la lechería. Zaragoza: Acribia, 1991. p. 181-226.

MARTINS, M. E. P.; NICOLAU, E. S.; MESQUITA, A. J.; NEVES, R. B. S.; ARRUDA, M. T. Qualidade de leite cru produzido e armazenado em tanques de expansão no estado de Goiás. Ciência Animal Brasileira, Goiânia, v. 9, n. 4, p. 1152-1158, 2008.

MATTOS, M. R.; BELOTI, V.; TAMANINI, R.; MAGNANI, D. F.; NERO, L. A.; BARROS, M. A. F.; PIRES, E. M. F.; PAQUEREAU, B. P. D. Qualidade do leite cru produzido na região do agreste de Pernambuco, Brasil. Semina: Ciências Agrárias, Londrina, v. 31, n. 1, p. 173-182, 2010.

MELO, B A.; SANTOS, T. M. C.; BARBOSA, Y. R. S.; MOURA, C. T. R.; MONTALDO, Y. C. Aspectos microbiológicos de amostras de leite cru coletadas no município de Major Isidoro - Alagoas. Revista Verde de Agricultura e Desenvolvimento Sustentável, Mossoró, v. 5, n. 5, p. 1-5, 2010.

MUIR, D. D. The fresh- life of dairy products: 1 . factors influencing raw milk and fresh products. Journal of the Society of Dairy Technology, Cumbria, v. 49, n. 1, p. 2432, 1996.

MUIR, D. D. The microbiology of heat-treated fluid milk products. In:_. Dairy microbiology: the microbiology of milk. 2. ed. New York: Elsevier Science, 1990. p. 209-243. 
NERO, L. A.; VIÇOSA, G. N.; PEREIRA, F. E. V. Qualidade microbiológica do leite determinada por características de produção. Ciência e Tecnologia de Alimentos, Campinas, v. 29, n. 2, p. 386-390, 2009.

NORO, G.; GONZÁLEZ, F. H. D.; CAMPOS, R.; DÜRR, J. W. Fatores ambientais que afetam a produção e a composição do leite em rebanhos assistidos por cooperativas no Rio Grande do Sul. Revista Brasileira de Zootecnia, Viçosa, v. 35, n. 3, p. 1129-1135, 2006.

PIMENTEL-GOMES, F. Curso de estatística experimental. Piracicaba: Nobel, 1990.

PINTO, C. L. O.; MARTINS, M. L.; VANETTI, M. C. D. Qualidade microbiológica do leite cru refrigerado e isolamento de bactérias psicrotróficas proteolíticas. Ciência e Tecnologia de Alimentos, Campinas, v. 26, n. 3, p. 645-651, 2006.

ROBINSON, R. K. Microbiologia de la leche. Zaragoza: Acribia, 1987.

SANTANA, E. H. W.; BELOTI, V.; BARROS, A. F.; MORAES, L. B.; GUSMÃO, V. V.; PEREIRA, M. S. Contaminação do leite em diferentes pontos do processo de produção: i. microrganismos aeróbios mesófilos e psicrotróficos. Semina: Ciências Agrárias, Londrina, v. 22, n. 2, p. 145-154, 2001.

SANTANA, E. H. W.; BELOTI, V.; MÜLLER, E. E.; FERREIRA, M. A.; MORAES, L. B.; PEREIRA, M. S.; GUSMÃO, V. V. Contaminação do leite em diferentes pontos da produção leiteira: ii) microrganismos mesófilos, psicrotróficos e proteolíticos. Semina: Ciências Agrárias, Londrina, v. 25, n. 4, p. 349-358, 2004.

SILVA, L. C. C.; BELOTI, V.; TAMANINI, R.; OVIDIO, L.; MATTOS, M. R.; ARRUDA, A. M. C. T.; PIRES, E. M. F. Rastreamento de fontes da contaminação microbiológica do leite cru durante a ordenha em propriedades leiteiras do Agreste Pernambucano. Semina: Ciências Agrárias, Londrina, v. 32, n. 1, p. $267-$ 276, 2011.

SILVA, N.; JUNQUEIRA, V. C. A.; SILVEIRA, N. F. A.; TANIWAKI, M. H.; SANTOS, R. F. S.; GOMES, R. A. R. Manual de métodos de análise microbiológica de alimentos. 3. ed. São Paulo: Varela, 2007. 536 p.
SMITHWELL, N.; KAILASAPATHY, K. Psychrotrophic bacteria in pasteurized milk: problems with shelf life. The Australian Journal of Dairy Technology, Melbourne, v. 50, n. 1, p. 28-31, 1995.

SORHAUNG, T.; STEPANIAK, L. Psychrotrophs and their enzymes in milk and dairy products: quality aspects. Trends in Food Science \& Technology, Norwich, v. 8, n. 2, p. 35-41, 1997.

STATSOFT, Inc. STATISTICA 8.0 for windows [Data analysis software system]. Tulsa: Statsof, 2008.

SUHREN, G. Producer microorganisms. In: MCKELLAR, R. C. (Ed.). Enzymes of Psychrotrophs in raw foods. CRC Press: Boca Raton, 1989. p. 3-34.

TEBALDI, V. M. R.; OLIVEIRA, T. L. C.; BOARI, C. A.; PICCOLI, R. H. Isolamento de coliformes, estafilococos e enterococos de leite cru provenientes de tanques de refrigeração por expansão comunitários: identificação, ação lipolítica e proteolítica. Ciência e Tecnologia de Alimentos, Campinas, v. 28, n. 3, p. 753-760, 2008.

VALLIN, V. M.; BELOTI, V.; BATTAGLINI, A. P. P.; TAMANINI, R.; FAGNANI, R.; ANGELA, H. L.; SILVA, L. C. C. Melhoria da qualidade do leite a partir da implantação de boas práticas na ordenha de 19 municípios da região central do Paraná. Semina: Ciências Agrárias, Londrina, v. 30, n. 1, p. 181-188, 2009.

VIDAL-MARTINS, A. M. C.; SALOTTI, B. M.; ROSSI JUNIOR, O. R.; PENNA, A. L. B. Evolução do índice proteolítico e do comportamento reológico durante a vida de prateleira de leite UAT/UHT. Ciência e Tecnologia de Alimentos, Campinas, v. 25, n. 4, p. 698-704, 2005.

WALSTRA, P.; WOUTERS, J. T. M.; GEURTS, T. J. Dairy science and technology. 2. ed. Boca Raton: CRC Press; London: Taylor \& Francis, 2006. 782 p.

WASHAM, C. J.; OLSON, H. C.; VEDAMUTHU, E. R. Heat-resistant psychrotrophic bacteria isolated from pasteurized milk. Journal of Food Protection, Des Moines, v. 40, n. 2, p. 101-108, 1977.

YAMAZI, A. K.; MORAES, P. M.; VIÇOSA, G. N.; ORTOLANI, M. B. T.; NERO, L. A. Práticas de produção aplicadas no controle de contaminação microbiana na produção de leite cru. Bioscience Journal, Uberlândia, v. 26, n. 4, p. 610-618, 2010. 